\title{
Serum and red blood cell antioxidant status in patients with bronchial asthma
}

\author{
Hüseyin Vural $M D^{1}$, Kürsat Uzun $\mathrm{MD}^{2}$ \\ ${ }^{1}$ Department of Biochemistry, Faculty of Medicine, Harran University, Sanliurfa, Turkey; \\ ${ }^{2}$ Department of Chest Diseases, Faculty of Medicine, Yuzuncu Yil University, Van, Turkey
}

\section{H Vural, K Uzun. Serum and red blood cell antioxidant status in patients with bronchial asthma. Can Respir J 2000;7(6):476-480.}

Levels of vitamin C, ceruloplasmin, transferrin and albumin in serum, and glutathione in red blood cells were investigated in 40 patients with asthma to determine whether their antioxidant status was different from healthy subjects. Serum vitamin $\mathrm{C}$ and albumin levels were lower in the patient group $(36.91 \pm 12.50 \mu \mathrm{M}$ and $46.2 \pm 3.0 \mathrm{~g} / \mathrm{L}$, respectively) than in 43 healthy volunteers $(53.38 \pm 13.06 \mu \mathrm{M}$ and $48.8 \pm 2.1 \mathrm{~g} / \mathrm{L}$, $\mathrm{P}<0.001$ and $\mathrm{P}<0.05$, respectively). However, erythrocyte glutathione and serum ceruloplasmin levels were higher in the patient group $(0.59 \pm 0.11 \mathrm{~mol} / \mathrm{mol}$ hemoglobin and $442 \pm 73 \mu \mathrm{mol} / \mathrm{L}$, respectively) than in controls $(0.49 \pm 0.09 \mathrm{~mol} / \mathrm{mol}$ hemoglobin and $308 \pm 47 \mu \mathrm{mol} / \mathrm{L}$, $\mathrm{P}<0.001$ and $\mathrm{P}<0.001$, respectively). No difference was observed in transferrin levels between the groups. The results suggest that reactive oxygen species may be a contributing factor in patients with asthma, causing changes in serum vita$\min \mathrm{C}$, ceruloplasmin and erythrocyte glutathione levels.

Key Words: Albumin; Asthma; Ceruloplasmin; Glutathione; Transferrin; Vitamin $C$

\section{Les taux d'antioxydants dans le sérum et les globules rouges de patients atteints d'asthme bronchique}

RÉSUMÉ : Les taux sériques de vitamine C, de céruloplasmine, de transferrine et d'albumine et les taux de glutathion des érythrocytes ont été évalués chez 40 patients souffrant d'asthme afin de déterminer si leur statut à l'égard des antioxydants était différent de celui de sujets en bonne santé. Les taux sériques de vitamine $\mathrm{C}$ et d'albumine étaient plus faibles chez les patients $(36,91 \pm 12,50 \mu \mathrm{m}$ et $46,2 \pm 3,0 \mathrm{~g} / \mathrm{L}$, respectivement) que chez les 43 témoins en bonne santé $(53,38 \pm 13,06 \mu \mathrm{m}$ et $48,8 \pm 2,1 \mathrm{~g} / \mathrm{L} ; p<0,001$ et $p<0,05$, respectivement). Par contre, les taux de glutathion des érythrocytes et les taux sériques de céruloplasmine étaient plus élevés chez les patients $(0,59 \pm 0,11 \mathrm{~mol} / \mathrm{mol}$ d'hémoglobine et $442 \pm 73 \mathrm{mmol} / \mathrm{L}$, respectivement) que chez les témoins $(0,49 \pm 0,09 \mathrm{~mol} / \mathrm{mol}$ d'hémoglobine et $308 \pm 47 \mu \mathrm{m} / \mathrm{L}, p<0,001$ et $p<0,001$, respectivement). Aucune différence n'a été observée quant au taux de transferrine entre les deux groupes. Les résultats donnent à penser que, dans l'asthme, les espèces qui réagissent à l'oxygène pourraient constituer un facteur contributif provoquant des changements des taux sériques de vitamine $C$ et de céruloplasmine et des taux de glutathion des érythrocytes.

\begin{abstract}
A sthma is characterized by reversible airflow obstruction and the presence of chronic inflammation of the airways. Cells involved in the asthmatic inflammatory process have been shown to generate increased amounts of reactive
\end{abstract}

oxygen species (ROS) (1-3), and levels of ROS generation correlate with asthma severity (4). ROS, released from eosinophils, alveolar macrophages and neutrophils, appear to play a key role in asthma. They may directly contract smooth mus- 
cle in the airways, stimulate histamine release from mast cells, stimulate mucous secretion and interact with alpha1-protease inhibitor (5-7). Neutrophils as well as eosinophils are increased in number after antigen inhalation challenge, and may be activated in patients with asthma (8).

To prevent the damage caused by ROS, multiple defence systems - collectively called antioxidants - are present in serum, as well as in erythrocytes and the lungs (5). These defence systems consist of both enzymatic and nonenzymatic antioxidants. The major enzymatic antioxidants are superoxide dismutase (SOD), which degrades superoxide anion and catalase, glutathione peroxidase and the glutathione oxidation-reduction system, which inactivates hydrogen peroxide and hydroperoxides (9). However, nonenzymatic antioxidants such as ceruloplasmin, an acute phase reactant, transferrin and albumin are considered antioxidants because they bind oxidation-reduction active metals and limit the production of metal-catalyzed free radicals (10-12). Essential nutrients such as vitamins $\mathrm{C}$ and $\mathrm{E}$ also protect against reactive oxygen metabolite-mediated cellular damage, through their free radical scavenging properties (13). Vitamin $\mathrm{C}$ is the major antioxidant present in the airway surface liquid of the lung, and it may protect against endogenous agents, as well as against exogenous agents such as cigarette smoke and environmental air pollutants (5). The aim of the present study was to investigate possible changes in antioxidant levels in the serum and erythrocytes of patients with asthma.

\section{PATIENTS AND METHODS}

The study included 40 patients with asthma and 43 healthy volunteers. The asthma group comprised 22 women and 18 men, with ages ranging from 18 to 70 years $(37.8 \pm 14.2$ years). The control group comprised 24 healthy women and 19 healthy men, aged 21 to 68 years $(36.2 \pm 11.7$ years). None of the participants in the study had eczema, hay fever or recurrent respiratory symptoms. Patients with asthma were selected from the Sanliurfa State Hospital, Sanliurfa, Turkey. The diagnosis of asthma was established according to American Thoracic Society criteria (14). All patients had reversible airflow limitation, showing a minimum $12 \%$ increase in their forced expiratory volume in $1 \mathrm{~s}\left(\mathrm{FEV}_{1}\right)$ after inhalation of a beta-mimetic. Mean baseline $\mathrm{FEV}_{1}$ was $75.2 \%$ predicted. None of the patients had diabetes mellitus, liver or kidney diseases, or thyroid dysfunction. During the study, all patients were taking a beta-mimetic (terbutaline, salbutamol, etc) and an antihistaminic, mast cell-stabilizing agent such as cromolin sodium. None received systemic or inhaled corticosteroid treatment during the study.

Blood samples were obtained from patients in the morning after an overnight fast. Samples were centrifuged at $3000 \mathrm{~g}$ for $15 \mathrm{~min}$ at room temperature. All measurements were taken immediately after serum preparation. Other blood samples were put into heparinized tubes to separate the erythrocytes from the plasma. Plasma and buffy coats on the top of the erythrocyte pellet were removed by a pipette, and the remaining erythrocyte pellet was washed three times with $0.9 \%$ sa-
TABLE 1

Characteristics of $\mathbf{4 0}$ patients with bronchial asthma

\begin{tabular}{lc}
\hline Sex (M/F) & $18 / 22$ \\
Smoker (yes/no) & $0 / 40$ \\
Age (years) & $37.8 \pm 14.2$ \\
Height (cm) & $165 \pm 13$ \\
Weight (kg) & $73 \pm 11$ \\
FEV 1 (L) (\% predicted) & $75.2 \pm 6.9$ \\
Peak expiratory flow (L/s) (\% variability) & $20.4 \pm 5.2$ \\
Beta-agonist use (salbutamol/terbutaline) & $22 / 18$ \\
\hline
\end{tabular}

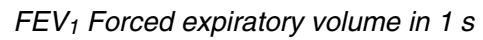

line and centrifuged at $1500 \mathrm{~g}$ for $5 \mathrm{~min}$. The samples were stored at $4^{\circ} \mathrm{C}$ until analysis later on the same day.

Vitamin $C$ levels were measured by the method of Omaye et al (15). Briefly, vitamin C in serum was oxidized by copper ions to form dehydroascorbic acid, which reacts with acidic 2,4-dinitrophenylhidrazine to form a red bishydrazone, measured as absorbance at $520 \mathrm{~nm}$. Ceruloplasmin levels were assessed by measuring its oxidative activity using p-phenylenediamine as the substrate, according to the method of Sunderman and Nomoto (16). Transferrin and albumin were measured with an automatic biochemistry analyzer (Hitachi 911 Analyzer, Boehringer Mannheim, Germany). Erythrocyte reduced glutathione concentration was determined by titration with $0.1 \mathrm{mmol} / \mathrm{L} 5,5^{\prime}$-dithiobis (2-nitrobenzoic acid) in a $0.1 \mathrm{~mol} / \mathrm{L}$ disodium phosphate buffer solution, $\mathrm{pH}$ 8. Formation of the reduced product thionitrobenzene was measured spectrophotometrically at $412 \mathrm{~nm}$ (17). Erythrocyte GSH levels were expressed as $\mu \mathrm{mol} / \mathrm{g}$ hemoglobin. Quality controls were included with the sample analysis (mean coefficients of variation for all analyses ranged from $3.8 \%$ to $5.2 \%$ ); also, commercial two-point control standards were included with each analysis to calibrate instruments.

Mean \pm standard deviation values of all variables in serum were calculated for the patient and control groups. The Student's $t$-test was used to compare means, and $\mathrm{P}<0.05$ was considered significant. Pulmonary function and other serum and erythrocyte variables were tested by intracorrelational analysis.

\section{RESULTS}

Characteristics of patients are shown in Table 1. There were no correlations among $\mathrm{FEV}_{1}$, peak flow rate, and levels of vitamin $\mathrm{C}$, ceruloplasmin, transferrin, albumin and GSH. Mean serum vitamin C, ceruloplasmin, transferrin and albumin levels, and erythrocyte GSH levels of patients and controls, together with Student's $t$-test results, are given in Table 2. Large differences in the variables were found between the patient and control groups. Serum vitamin C levels in the patient group were lower than those in the control group $(\mathrm{P}<0.001)$, whereas ceruloplasmin levels in the patient group were higher $(\mathrm{P}<0.001)$. Albumin levels were significantly higher in the control group than in the patient group $(\mathrm{P}<0.05)$. No difference was observed in the transferrin levels between the patient and control groups. As seen in 
TABLE 2

Vitamin C, ceruloplasmin, transferrin and albumin levels in serum, and reduced glutathione (GSH) levels in erythrocytes from patients with bronchial asthma

\begin{tabular}{|c|c|c|c|c|c|}
\hline & \multicolumn{4}{|c|}{ Serum } & \multirow{2}{*}{$\begin{array}{c}\text { Erythrocyte } \\
\text { GSH (mol/mol hemoglobin) }\end{array}$} \\
\hline & Vitamin $\mathbf{C}(\mu \mathrm{M})$ & Ceruloplasmin ( $\mu \mathrm{mol} / \mathrm{L})$ & Transferrin (g/L) & Albumin (g/L) & \\
\hline $\begin{array}{l}\text { Bronchial } \\
\text { asthma }(n=40)\end{array}$ & $36.91 \pm 12.50$ & $442 \pm 73$ & $2.05 \pm 0.58$ & $46.2 \pm 3.0$ & $0.59 \pm 0.11$ \\
\hline $\mathrm{P}$ & $<0.001$ & $<0.001$ & NS & $<0.05$ & $<0.001$ \\
\hline
\end{tabular}

Results are expressed as mean $\pm S D$. NS Not significant $(P>0.05)$

Table 2, erythrocyte GSH levels in patients were higher than those in controls. There were no differences in the numbers of cigarette smokers and nonsmokers in the patient and control groups.

\section{DISCUSSION}

Patients with asthma have increased numbers of low density or hypodense eosinophils in blood, bronchoalveolar lavage (BAL) fluid and lung tissue. This association suggests that low density eosinophils play a role in asthma $(18,19)$ and may be highly relevant cells in the asthma process. Sedgwich et al (20) found that when purified suspensions of either eosinophils or neutrophils were activated by $1 \mathrm{ng} / \mathrm{mL}$ phorbol myristate acetate, differences were observed in both the rate and the total amount of superoxide generated by the cell suspensions. Eosinophils (both normal and low density) from patients with asthma generated more superoxide than matching neutrophils. Moreover, the generation of superoxide by neutrophils from patients with asthma during a reaction lasting 30 to $60 \mathrm{~min}$ was significantly greater than neutrophils from controls. These findings suggest that patients with asthma are subjected to more free oxygen radicals than are those without asthma. Rahman et al (21) found that plasma trolox-equivalent antioxidant capacity was low in patients presenting with acute exacerbations of chronic obstructive pulmonary disease or asthma, with increases in plasma lipid peroxidation products.

In a healthy state, when ROS production is low, lipid peroxidation is inhibited by the combined activities of various antioxidants present in plasma. However, in the event of excessive ROS production, as is the case in asthma, this protection may be inadequate. Vitamin $\mathrm{C}$ is highly water soluble and a strong reducing agent (22). It has recently been shown that, in addition to enhanced lipid peroxidation, levels of vitamins $\mathrm{C}$ and $\mathrm{E}$ are decreased in the BAL fluid of guinea pigs after an asthmatic response (23). An increasing body of data suggests that low consumption of fresh fruit containing vitamin $\mathrm{C}$ is associated with decreased lung function in both children and adults (24). In 1990, Schwartz and Weiss (25) first reported an inverse association between bronchitis and wheezing, and both dietary and plasma vitamin C levels in a representative sample of the adult population in the United States. In our study, the level of vitamin C was lower in patients with asthma than in the control group. Kalaycý et al (26) reported that plasma vitamin $\mathrm{C}$ concentration was decreased in asthmatic children. Kelly et al (27) found that vitamin $\mathrm{C}$ concentration was low in the fluid lining the lungs of patients with asthma. One possible explanation for the low level of vitamin $C$ is that asthmatic patients eat less vitaminrich foods in their diet. This explanation is supported by recent studies (28-31). The other possible explanation is that vitamin $C$ is metabolized at an increased rate as part of a defence mechanism against the ongoing oxidative burden.

The same property makes vitamin $\mathrm{C}$ an excellent antioxidant, capable of scavenging a wide variety of oxidants. For example, ascorbate has been shown to scavenge effectively superoxide, hydrogen peroxide, hypochlorous acid, aqueous peroxyl radicals and singlet oxygen. During its antioxidation activity, ascorbate undergoes a two-electron oxidation to dehydroascorbic acid (the oxidized form of vitamin C), with the intermediate formation of the relatively unreactive ascorbyl radical. Although dehydroascorbic acid is relatively unstable and hydrolyzes readily to L-2,3-diketogulonic acid, it can be reduced back to ascorbate by a variety of cells or thiols such as homocysteine and GSH. Plasma ascorbate plays an important role in protecting plasma lipids from ROS attack; however, it is rapidly oxidized when challenged by oxidants released from activated polymorphonuclear cells (22). This rapid depletion may be the reason for the low serum ascorbate values recorded in our study $(\mathrm{P}<0.001)$. Under these conditions, endogenously synthesized proteins in the liver, such as ceruloplasmin and transferrin, may play a significant role in scavenging ROS and their harmful lipid peroxidation products. It has been shown that ceruloplasmin can scavenge free radicals as well as transition metals, and thereby protect against lipid peroxidation $(10,11)$. Two research teams $(32,33)$ observed that when malondialdehyde levels increased as the result of oxidative stresses, ceruloplasmin activity increased in parallel to the oxidant stress. In addition, Boljevic et al (34) found that the concentration of plasma malondialdehyde increased in patients with acute asthma. Moreover, the relation between induced and spontaneous luminoldependent chemiluminescence of plasma suggested that antiperoxide plasma activity was reduced; in remission, plasma malondialdehyde decreased but did not reach the normal range.

GSH is present in most mammalian cells. It is an antioxidant, participating in many biological phenomena (9). Few data exist regarding glutathione levels in the erythrocytes of patients with asthma (35). GSH protects cells against oxygen 
radicals and toxic compounds. Both animal and human studies have shown that GSH levels may increase during oxidative stress (36). Increased levels of GSH were found in the BAL fluid of patients with asthma, erythrocytes of patients with chronic occupational lung disorders and erythrocytes of volunteers participating in exercise training (36-38). We observed an approximately $20 \%$ increase in GSH levels in the erythrocytes of patients with asthma $(\mathrm{P}<0.001)$. This increase may occur in response to the production of ROS because ROS require GSH for detoxification. Pennings et al (39) reported that the level of GSH was elevated in the erythrocytes of patients with asthma and decreased after steroid inhalation. This observed elevation in erythrocyte GSH may reflect an increased oxidative burden (39). The GSH concentration in bronchial fluid (but not in red blood cells) was shown to be higher in patients with asthma; a similar trend was seen in the alveolar fluid (36). In another study (27), oxidized GSH concentrations in bronchial washings and BAL fluid were higher in patients with asthma than in the control group, indicating the presence of oxidative stress in the airways. Glutathione peroxidase, an enzyme present in large amounts in erythrocytes, needs GSH to detoxify hydrogen peroxide. In our study, GSH concentration was higher in patients with asthma than in the control group, which may be explained by increased oxidative stress. Indeed, extracellularly oxidized vitamin $\mathrm{C}$ is reduced by intracellular GSH and then released into the plasma (40). Thus, the GSH level reflects the antioxidant capability of the erythrocytes in such circumstances.

\section{CONCLUSIONS}

The present study shows that a vitamin $\mathrm{C}$ deficiency and a high GSH level, due to increased oxidative stress, may be related to asthma. Future studies evaluating antioxidant effects in asthma need to examine the products of increased ROS activity, such as malondialdehyde, oxidized sulfhydryl groups on albumin and lipid hydroperoxides.

\section{REFERENCES}

1. Vachier I, Damon M, Le Doucen C, et al. Increased oxygen species generation in blood monocytes of asthmatic patients. Am Rev Respir Dis 1992;146:1161-6.

2. Vachier I, Chanez P, Le Doucen C, Damon M, Descomps B, Godard P. Enhancement of reactive oxygen species formation in stable and unstable asthmatic patients. Eur Respir J 1994;7:1585-92.

3. Chanez P, Dent G, Yukawa T, Barnes PJ, Chung KF. Generation of oxygen free radicals from blood eosinophils from asthma patients after stimulation with PAF or phorbol ester. Eur Respir J 1990;3:1002-7.

4. Cluzel M, Damon M, Chanez P, et al. Enhanced alveolar cell luminol-dependent chemiluminescence in asthma. J Allergy Clin Immunol 1987;80:195-201.

5. Hatch GE. Asthma, inhaled oxidants, and dietary antioxidants. Am J Clin Nutr 1995;61(Suppl 3):625-30S.

6. Pryor WA. The free radical chemistry of cigarette smoke and the inactivation of alpha-1-protinase inhibitor. In: Mittman C, Taylor JC, eds. Emphysema and Proteolytic Damage, vol 2. New York: Academic Press, 1986.

7. Pryor WA, Dooley MM. Inactivation of human alpha-1-proteinase inhibitor by cigarette smoke: effect of smoke phase and buffer. Am Rev Respir Dis 1985;131:941-3.

8. Doelman CJ, Bast A. Oxygen radicals in lung pathology. Free Radic Biol Med 1990;9:381-400.
9. Repine JE, Bast A, Lankhorst I, and the Oxidative Stress Study Group. Oxidative stress in chronic obstructive pulmonary disease. Am J Respir Crit Care Med 1997; 156:341-57.

10. Biemond P, Swaak AJG, Koster JF. Protective factors against oxygen free radicals and hydrogen peroxide in rheumatoid arthritis synovial fluid. Arthritis Rheum 1984;27:760-5.

11. Gutteridge JMC. Antioxidant properties of the proteins ceruloplasmin, albumin and transferrin. A study of their activity in serum and synovial fluid from patients with rheumatoid arthritis. Biochim Biophys Acta 1986;869:119-27.

12. Halliwell B, Gutteridge JMC. The antioxidants of human extracellular fluids. Arch Biochem Biophys 1990;280:1-8.

13. Conner EM, Grisham MB. Inflammation, free radicals, and antioxidants. Nutrition 1996;12:274-7.

14. American Thoracic Society. Standards for the diagnosis and care of patients with chronic obstructive pulmonary disease (COPD) and asthma. Am Rev Respir Dis 1987;136:225-44.

15. Omaye ST, Turnbull JD, Sauberlich HE. Selected methods for the determination of ascorbic acid in animal cells, tissues, and fluids. Methods Enzymol 1979;62:3-11.

16. Sunderman FW Jr, Nomoto S. Measurement of human serum ceruloplasmin by its p-phenylenediamine oxidase activity. Clin Chem 1970;16:903-10.

17. Beutler E, Duran O, Kelly BM. Improved method for the determination of blood glutathione. J Lab Clin Med 1963;61:882-8.

18. Fukuda T, Gleich GJ. Heterogeneity of human eosinophils. J Allergy Clin Immunol 1989;83:369-73.

19. Frick WE, Sedgwick JB, Busse WW. The appearance of hypodense eosinophils in antigen-dependent late phase asthma. Am Rev Respir Dis 1989;139:1401-6.

20. Sedgwich JB, Geiger KM, Busse WW. Superoxide generation by hypodense eosinophils from patients with asthma. Am Rev Respir Dis 1990;142:120-5.

21. Rahman I, Morrison D, Donaldson K, MacNee W. Systemic oxidative stress in asthma, COPD, and smokers. Am J Respir Crit Care Med 1996;154:1055-60.

22. Frei B, Stocker R, Ames BN. Antioxidant defenses and lipid peroxidation in human blood plasma. Proc Natl Acad Sci USA 1988;85:9748-52.

23. Shvedova AA, Kisin ER, Kagan VE, Karol MH. Increased lipid peroxidation and decreased antioxidants in lungs of guinea pigs following an allergic pulmonary response. Toxicol Appl Pharmacol 1995; 132:72-81.

24. Schwartz J, Weiss ST. Relationship between dietary vitamin C intake and pulmonary function in the First National Health and Nutrition Examination Survey (NHANES I). Am J Clin Nutr 1994;59:110-4.

25. Schwartz J, Weiss ST. Dietary factors and their relation to respiratory symptoms. The Second National Health and Nutrition Examination Survey. Am J Epidemiol 1990;132:67-76.

26. Kalaycý O, Besler T, Kýlýnc K, Sekerel BE, Saraclar Y. Serum levels of antioxidant vitamins (alpha-tocopherol, beta-carotene, and ascorbic acid) in children with bronchial asthma. Turk J Pediatr 2000;42:17-21.

27. Kelly FJ, Mudway I, Blomberg A, Frew A, Sandström T. Altered lung antioxidant status in patients with mild asthma. Lancet 1999;354:482-3.

28. Forastiere F, Pistelli R, Sestini P, et al, on behalf of the SIDRIA Collaborative Group, Italy. Consumption of fresh fruit rich in vitamin C and wheezing symptoms in children. Thorax 2000;55:283-8.

29. Bodner C, Godden D, Brown K, Little J, Ross S, Seaton A, on behalf of Aberdeen WHEASE Study Group. Antioxidant intake and adult-onset wheeze: a case-control study. Eur Respir J 1999;13:22-30.

30. Butland BK, Strachan DP, Anderson HR. Fresh fruit intake and asthma symptoms in young British adults: confounding or effect modification by smoking. Eur Respir J 1999;13:744-50.

31. Baker JC, Tunnicliffe WS, Duncanson RC, Ayres JG. Dietary antioxidants and magnesium in type 1 brittle asthma: a case control study. Thorax 1999;54:115-8.

32. Ozgunes H, Gurer H, Tuncer S. Correlation between plasma malondialdehyde and ceruloplasmin activity values in rheumatoid arthritis. Clin Biochem 1995;28:193-4.

33. Gambhir JK, Lali P, Jain AK. Correlation between blood antioxidant levels and lipid peroxidation in rheumatoid arthritis. Clin Biochem 1997;30:351-5.

34. Boljevic S, Daniljak IG, Kogan AH. [Changes in free radicals and possibility of their correction in patients with bronchial asthma]. Vojnosanit Pregl 1993;50:3-18. 
35. Novak Z, Nemeth I, Gyurkovits K, Varga SI, Matkovics B. Examination of the role of oxygen free radicals in bronchial asthma in childhood. Clin Chim Acta 1991;201:247-51.

36. Smith LJ, Houston M, Anderson J. Increased levels of glutathione in bronchoalveolar lavage fluid from patients with asthma. Am Rev Respir Dis 1993;147:1461-4.

37. Borm PJA, Bast A, Wouters EFM, Slangen JJ, Swaen GMH,

De Boorder TJ. Red blood cell anti-oxidant parameters in healthy elderly subjects versus silicosis patients. Free Radic Res Commun 1987;3:117-27.

38. Evelo CTA, Palmen NGM, Artur Y, Janssen GME. Changes in blood glutathione concentrations, and in erythrocyte glutathione reductase and glutathione S-transferase activity after running training and after participation in contests. Eur J Appl Physiol Occup Physiol 1992;64:354-8.

39. Pennings HJ, Borm PJA, Evelo CTA, Wouters EFM. Changes in levels of catalase and glutathione in erythrocytes of patients with stable asthma, treated with beclomethasone dipropionate. Eur Respir J 1999;13:1260-6.

40. Orringer EP, Roer MES. An ascorbate-mediated transmembranereducing system of the human erythrocyte. J Clin Invest 1979;63:53-8. 


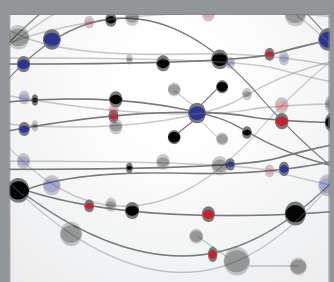

The Scientific World Journal
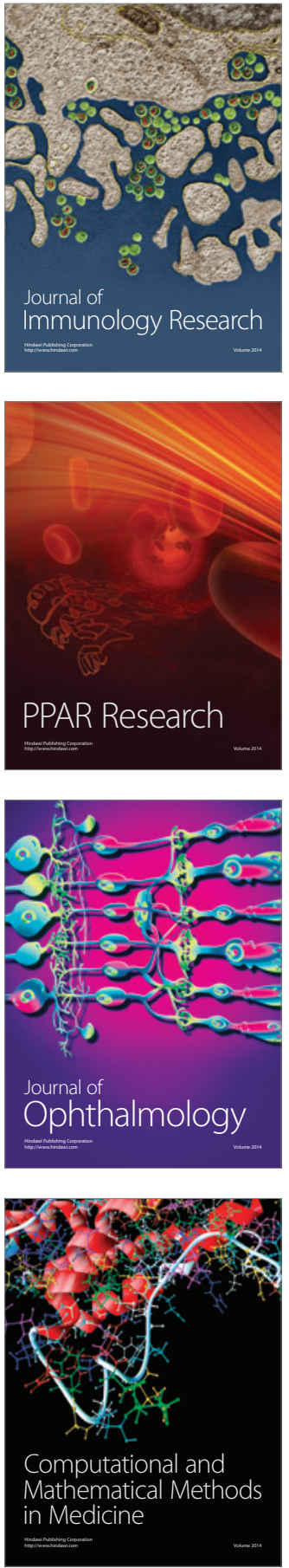

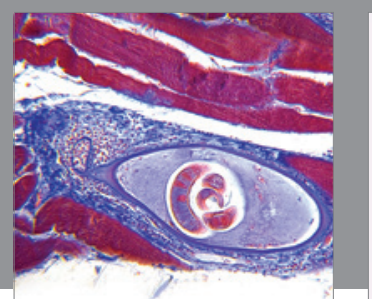

Gastroenterology Research and Practice

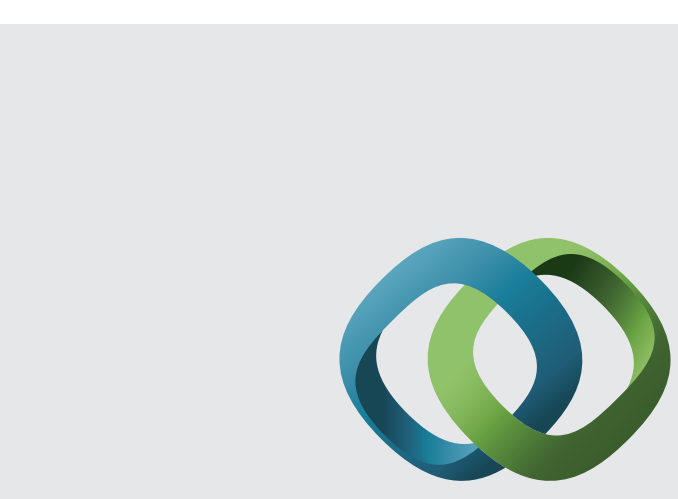

\section{Hindawi}

Submit your manuscripts at

http://www.hindawi.com
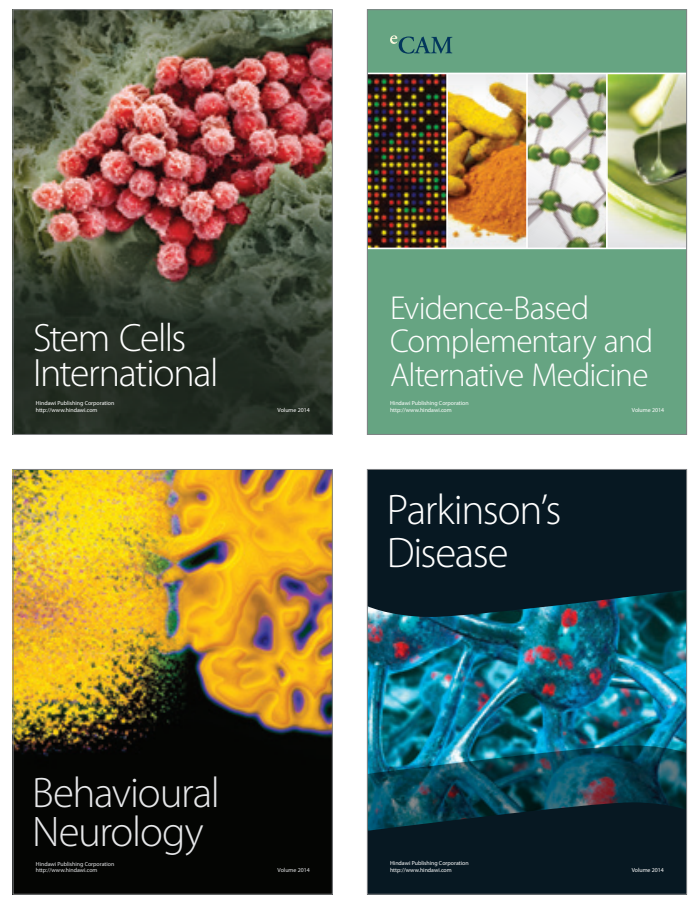
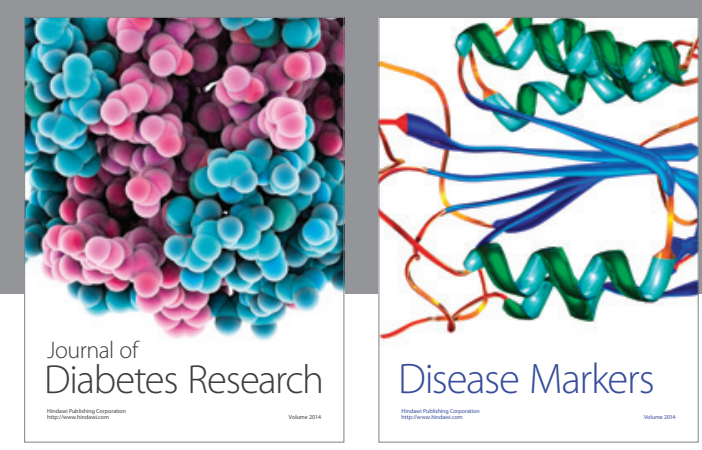

Disease Markers
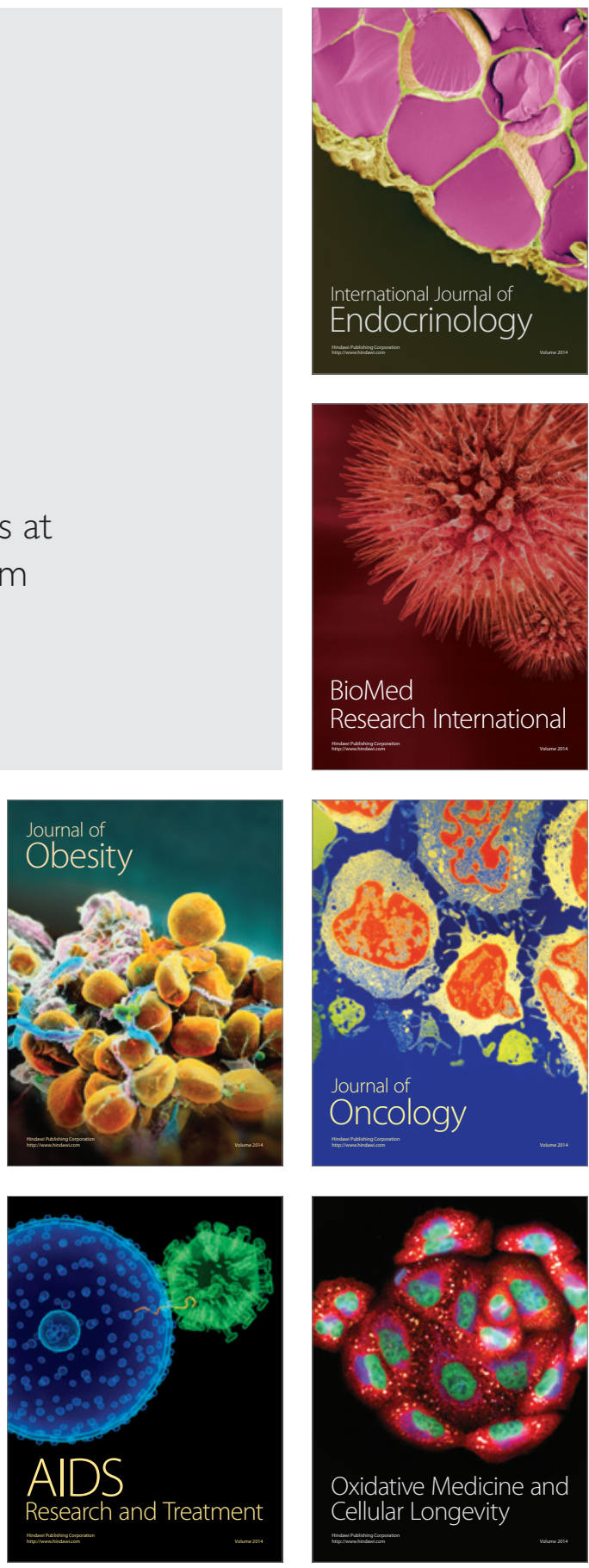